\title{
Knowledge about health and disease in obese patients after myocardial infarction. An observational study
}

\author{
Corresponding author: \\ Łukasz Pietrzykowski, MD \\ Department of Health Promotion, \\ Collegium Medicum, Nicolaus \\ Copernicus University \\ ul. Łukasiewicza 1 \\ 85-821 Bydgoszcz, Poland \\ tel. 525855801 \\ e-mail: \\ lukasz.pietrzykowski@cm.umk.pl
}

Medical Research Journal 2017 Volume 2, Number 4, 135-140 10.5603/MRJ.2017.0018 Copyright (C) 2017 Via Medica ISSN 2451-2591

\begin{abstract}
Introduction. Conscious implementation of a therapeutic plan immediately after discharge from hospital is pivotal in myocardial infarction survivors. Obesity and overweight are known as factors increasing the risk of adverse cardiovascular events and worsening long-term clinical outcome.

The aim of the study was to assess the knowledge regarding cardiovascular diseases in patients with myocardial infarction undergoing in-hospital brochure-based education in relation to the prevalence of overweight and obesity. Patients and methods. A prospective, single-centre, cohort, observational study was conducted in 228 patients hospitalised due to myocardial infarction (women $n=52$, men $n=176$ ). A dedicated questionnaire containing 20 single-choice questions was applied for the knowledge assessment. Patients were divided into three groups depending on the BMl level (normal, overweight, obesity).

Results. Comparison of patients' knowledge at baseline and on the day of discharge revealed a significant increase of overall result $(p=0.0264)$ and of knowledge about prophylaxis $(p=0.0115)$. Multivariate analysis showed education level $(-5.82 \pm 2.576, p=0.025)$ and BMI $(-4.54 \pm 1.771, p=0.011)$ as independent factors determining the overall increase in patients' knowledge.

Conclusions. Educational interventions in overweight and obese patients should be intensified. The brochure is an effective educational tool.

Key words: body mass index, obesity, myocardial infarcion, patient education
\end{abstract}

Med Res J 2017; 2 (4): 135-140

\section{Introduction}

The increasing number of overweight and obese people is a global social, economic, and medical problem [1-4]. According to estimates published in The Global Burden of Disease Study 2013 [3], the percentage of people with BMl above $25 \mathrm{~kg} / \mathrm{m}^{2}$ in 2013 was $37 \%$ in men and $38 \%$ in women. This accounted for an increase of $8 \%$ as compared to 1980 [3].

A prospective population study, aiming to assess the mortality causes in relation to the body mass index (BMI), showed that BMI above $22.5 \mathrm{~kg} / \mathrm{m}^{2}$ was associated with increased mortality. For every $5 \mathrm{~kg} / \mathrm{m}^{2}$ of BMI increase, mortality increase due to diabetes (by 120\%), vascular diseases (by 40\%), kidney and liver diseases (by $60-80 \%$ ), respiratory diseases (by $20 \%$ ), and cancer (by 10\%) were observed [5]. Moreover, excessive body weight contributed to the occurrence of emotional problems related to the reduction of self-esteem [6] and to worse cognitive functioning [7].
The aim of the study was to assess the knowledge regarding cardiovascular diseases in patients with myocardial infarction undergoing in-hospital brochure-based education in relation to the prevalence of overweight and obesity.

\section{Patients and Methods}

A prospective, single-centre, cohort, observational study was conducted in accordance with the principles contained in the Declaration of Helsinki. The study site received approval from the Local Ethics Committee to conduct the study (study approval reference number KB 248/2015). Each patient provided written, informed consent to participate in the study.

A dedicated questionnaire containing 20 single-choice questions regarding coronary artery disease was applied for the knowledge assessment. The questionnaire included questions about the awareness

\footnotetext{
* Autorzy równorzędni
} 
of disease symptoms, understanding the mechanisms of the disease, and knowledge about prevention. Each correct answer was awarded one point. The same questionnaire was completed within the first 48 hours after admission to the hospital and at the day of discharge. After the first examination of the knowledge, a purposely developed educational brochure was given to each patient. It contained all the information necessary to provide correct answers in the questionnaire. The effectiveness of education based on this brochure was assessed on the basis of a comparison of patients' knowledge at the beginning and at the end of hospitalisation.

Prisoners, soldiers, and people who were in any way dependent on the researchers, as well as patients with physical or mental limitations that did not allow them to fill out the questionnaires, were excluded from the study.

The study population consisted of 228 consecutive patients meeting the inclusion criteria hospitalised due to myocardial infarction at the Department of Cardiology of University Hospital No. 1 in Bydgoszcz. There were 176 men $(77.2 \%)$ and 52 women (22.8\%) aged from 30 to 91 years $(62.96 \pm 11.34)$ with $\mathrm{BMI}$ from 16.44 to $41.02(27.08 \pm 4.42)$. Obesity $(\mathrm{BMI} \geq 30)$ was found in 48 patients $(21 \%)$ and overweight $(25 \leq \mathrm{BMI}<30)$ in 104 (45.6\%). Patients were divided into three groups depending on the BMI level (normal, overweight, obesity).

The socio-demographic data are displayed in Table 1.

The applied definitions of coronary artery disease, hypertension, hypercholesterolaemia, nicotinism, diabetes, and family disease burden were based on the guidelines of the European Society of Cardiology [8].

The statistical analysis was performed using the Statistica 12.0 package (StatSoft, Tulsa, USA). Continuous variables were presented as medians with interquartile ranges and means with standard deviations. The Shapiro-Wilk test demonstrated non-normal distribution of the investigated continuous variables. Therefore, non-parametric tests were used for statistical analysis. Comparisons between two groups were performed with the Mann-Whitney unpaired rank sum test. For comparisons between three or more groups, the Kruskal-Wallis one-way analysis of variance was used. Spearmann's rank correlation was used to assess the relationship between two variables. Differences were considered significant at $P<0.05$.

To identify factors with independent influence on the ACDS score, multiple regression analysis was performed. For identification of the best statistical model, backward stepwise regression was applied. Variables with a $P$ value $<0.1$ in the univariate analysis were introduced into the multiple regression model. Subsequently, variables without significant impact $(P>0.05)$ were removed one after another from the multivariate model.

\section{Results}

Taking into account the division of patients into three groups: $\mathrm{BMI}<25,25 \leq \mathrm{BMI}<30$, and $\mathrm{BMI} \geq 30$, there were no differences in the level of knowledge at the first assessment (KA I), while at the second assessment (KA II), after educational intervention, a clear trend to obtain better results with smaller BMI values was observed. The increase in knowledge during hospitalisation was highest in patients with $\mathrm{BMI}<25$, and lowest in obese patients (Figure 1).

Significant differences were demonstrated in the increase of overall patients' knowledge ( $p=0.0264)$ and in the knowledge about prevention $(p=0.0115)$. A correlation between the increase of knowledge and BMI was observed $(R=-0.132, p=0.0471)$.

This regularity was noted in all assessed ranges of knowledge, but it was particularly expressed in relation to knowledge about prevention. The increase in knowledge in obese people was more than three-fold lower than in patients with $\mathrm{BMI}<25.0 ;(R=-0.1464, \mathrm{p}=0.0271)$.

The waist circumference did not differentiate patients' knowledge before education (KA I) and at the day of discharge (KA II).

The multivariate analysis showed that the level of education $(-5.82 \pm 2.576, p=0.025)$ and the BMI $(-4.54 \pm 1.771, p=0.011)$ are independent determinants of total knowledge increase, explaining $5.12 \%$ of variation $(R=0.226$; $R \wedge 2=0.05129$; $p=0.0428)$. Moreover, the level of education and the BMI $(-6.73 \pm 2.209, p=0.0026)$ were also independent factors influencing the increase of knowledge about prevention. Secondary or higher education was associated with a lower increase of knowledge $(-9.18 \pm 3.214$, $p=0.0047)$. The model explains only $7.46 \%$ of the variation of the increase in knowledge regarding prevention $(R=0.273 ; R \wedge 2=0.0746 ; p=0.00016)$.

\section{Discussion}

The educational brochure is an easy and relatively cheap educational tool that can be widely used by patients at any convenient time [9-10]. The patient's motivation to obtain the knowledge regarding the disease is a necessary condition for the effectiveness of education based on the brochure [11-13]. Our experience indicates that the educational brochure is often preferred by patients as a source of knowledge about health and disease [14-19].

According to a multivariate analysis, we have shown that education level and BMI are independent factors conditioning the increase in patients' knowledge. Di Chiara et al. [20] observed a significantly higher incidence of abdominal obesity, hypertension, meta- 
Table 1. Characteristics of the study population with regard to body mass index (BMI).

\begin{tabular}{|c|c|c|c|c|c|c|c|c|c|}
\hline \multirow[t]{2}{*}{ Variable } & \multicolumn{2}{|c|}{ Total } & \multicolumn{6}{|c|}{ Body Mass Index (BMI) } & \multirow[b]{2}{*}{$\mathbf{p}$} \\
\hline & $\begin{array}{l}\text { Amout } \\
n=228\end{array}$ & $\%$ & $\begin{array}{c}\mathrm{BMI}<25 \\
n=76\end{array}$ & $\%$ & $\begin{array}{c}25 \leq \mathrm{BMI}<30 \\
n=104\end{array}$ & $\%$ & $\begin{array}{c}\mathrm{BMI} \geq 30 \\
\mathrm{n}=\mathbf{4 8}\end{array}$ & $\%$ & \\
\hline Gender & & & & & & & & & 0.6706 \\
\hline Women & 52 & $22.80 \%$ & 20 & $26.31 \%$ & 22 & $21.15 \%$ & 10 & $20.83 \%$ & \\
\hline Men & 176 & $77.20 \%$ & 56 & $73.69 \%$ & 82 & $78.85 \%$ & 38 & $79.79 \%$ & \\
\hline Age & & & & & & & & & 0.2161 \\
\hline$<65$ years & 131 & $57.45 \%$ & 45 & $59.21 \%$ & 54 & $51.92 \%$ & 32 & $66.67 \%$ & \\
\hline$\geq 65$ years & 97 & $42.55 \%$ & 31 & $40.79 \%$ & 50 & $48.08 \%$ & 16 & $33.33 \%$ & \\
\hline Education & & & & & & & & & 0.5497 \\
\hline Primary education & 28 & $12.30 \%$ & 12 & $15.79 \%$ & 12 & $11.54 \%$ & 4 & $8.33 \%$ & \\
\hline Basic vocational education & 84 & $36.80 \%$ & 27 & $35.53 \%$ & 39 & $35.50 \%$ & 18 & $37.50 \%$ & \\
\hline Secondary education & 83 & $36.40 \%$ & 28 & $36.84 \%$ & 40 & $38.46 \%$ & 15 & $31.25 \%$ & \\
\hline Higher education & 33 & $14.50 \%$ & 9 & $11.84 \%$ & 13 & $12.50 \%$ & 11 & $22.92 \%$ & \\
\hline Employment status & & & & & & & & & 0.3518 \\
\hline Employed & 98 & $43.0 \%$ & 28 & $36.84 \%$ & 48 & $46.15 \%$ & 22 & $45.83 \%$ & \\
\hline Unemployed & 12 & $5.30 \%$ & 5 & $6.58 \%$ & 5 & $4.81 \%$ & 2 & $4.17 \%$ & \\
\hline Pensioner & 89 & $39.0 \%$ & 28 & $36.84 \%$ & 43 & $41.35 \%$ & 18 & $37.50 \%$ & \\
\hline Invalid & 29 & $12.70 \%$ & 15 & $19.74 \%$ & 8 & $7.69 \%$ & 6 & $12.50 \%$ & \\
\hline Economic status & & & & & & & & & 0.8987 \\
\hline Very good & 13 & $5.70 \%$ & 5 & $6.58 \%$ & 5 & $4.81 \%$ & 5 & $6.25 \%$ & \\
\hline Satisfactory & 201 & $88.16 \%$ & 65 & $85.53 \%$ & 93 & $89.42 \%$ & 43 & $89.58 \%$ & \\
\hline Bad & 14 & $6.14 \%$ & 6 & $7.89 \%$ & 6 & $5.77 \%$ & 2 & $4.17 \%$ & \\
\hline Very bad & 0 & - & - & - & - & - & - & - & \\
\hline Place of residence & & & & & & & & & 0.4295 \\
\hline Big city: > 100 thousand & 117 & $51.32 \%$ & 44 & $57.89 \%$ & 52 & $50.0 \%$ & 21 & $43.75 \%$ & \\
\hline inhabitants & 46 & $20.17 \%$ & 13 & $17.11 \%$ & 24 & $23.08 \%$ & 9 & $18.75 \%$ & \\
\hline $\begin{array}{l}\text { Small town: } \leq 100 \text { thousand } \\
\text { inhabitants } \\
\text { Village }\end{array}$ & 65 & $28.51 \%$ & 19 & $25.0 \%$ & 28 & $26.92 \%$ & 18 & $37.50 \%$ & \\
\hline Marital status & & & & & & & & & 0.0842 \\
\hline Single & 22 & $9.65 \%$ & 12 & $15.79 \%$ & 6 & $5.77 \%$ & 4 & $8.33 \%$ & \\
\hline In a relationship & 172 & $75.44 \%$ & 50 & $65.79 \%$ & 82 & $78.85 \%$ & 40 & $83.34 \%$ & \\
\hline Widow/ widower & 34 & $14.91 \%$ & 14 & $18.42 \%$ & 16 & $15.38 \%$ & 4 & $8.33 \%$ & \\
\hline Waist circumference * & & & & & & & & & $<0.0001$ \\
\hline Optimal & 123 & $53.95 \%$ & 65 & $85.53 \%$ & 58 & $55.77 \%$ & 0 & $0.0 \%$ & \\
\hline Risk & 58 & $25.44 \%$ & 11 & $14.47 \%$ & 29 & $27.88 \%$ & 18 & $37.50 \%$ & \\
\hline Pathology & 47 & $20.61 \%$ & 0 & $0.0 \%$ & 17 & $16.35 \%$ & 30 & $62.50 \%$ & \\
\hline Coronary artery disease & & & & & & & & & 0.7748 \\
\hline Yes & 106 & $46.49 \%$ & 34 & $44.74 \%$ & 51 & $49.04 \%$ & 21 & $43.75 \%$ & \\
\hline No & 122 & $53.51 \%$ & 42 & $55.26 \%$ & 53 & $50.96 \%$ & 27 & $56.25 \%$ & \\
\hline Hypertension & & & & & & & & & 0.4114 \\
\hline Yes & 144 & $63.16 \%$ & 48 & $63.16 \%$ & 62 & $59.62 \%$ & 34 & $70.83 \%$ & \\
\hline No & 84 & $36.84 \%$ & 28 & $36.84 \%$ & 42 & $40.38 \%$ & 14 & $29.17 \%$ & \\
\hline Hypercholesterolaemia & & & & & & & & & 0.1285 \\
\hline Yes & 119 & $52.19 \%$ & 39 & $51.32 \%$ & 49 & $47.12 \%$ & 31 & $64.58 \%$ & \\
\hline No & 109 & $47.81 \%$ & 37 & $48.68 \%$ & 55 & $52.88 \%$ & 17 & $35.42 \%$ & \\
\hline Nicotinism & & & & & & & & & 0.0393 \\
\hline Yes & 82 & $35.96 \%$ & 36 & $47.37 \%$ & 32 & $30.77 \%$ & 14 & $29.17 \%$ & \\
\hline No & 146 & $64.04 \%$ & 40 & $52.63 \%$ & 72 & $69.23 \%$ & 34 & $70.83 \%$ & \\
\hline Diabetes & & & & & & & & & 0.0477 \\
\hline Yes & 65 & $28.51 \%$ & 14 & $18.42 \%$ & 34 & $32.69 \%$ & 17 & $35.42 \%$ & \\
\hline No & 163 & $71.49 \%$ & 62 & $81.58 \%$ & 70 & $67.31 \%$ & 31 & $64.58 \%$ & \\
\hline Family disease burden & & & & & & & & & 0.6923 \\
\hline Yes & 132 & $57.89 \%$ & 47 & $61.84 \%$ & 58 & $55.77 \%$ & 27 & $56.25 \%$ & \\
\hline No & 96 & $42.11 \%$ & 29 & $38.16 \%$ & 46 & $44.23 \%$ & 21 & $43.75 \%$ & \\
\hline
\end{tabular}

*Waist circumference - women: optimal $\leq 80 \mathrm{~cm}, 80 \mathrm{~cm}<$ risk $\leq 88 \mathrm{~cm}$, pathology $>88 \mathrm{~cm}$; men: optimal $\leq 94 \mathrm{~cm}, 94 \mathrm{~cm}<$ risk $\leq 102 \mathrm{~cm}$, pathology $>102 \mathrm{~cm}[8]$ 


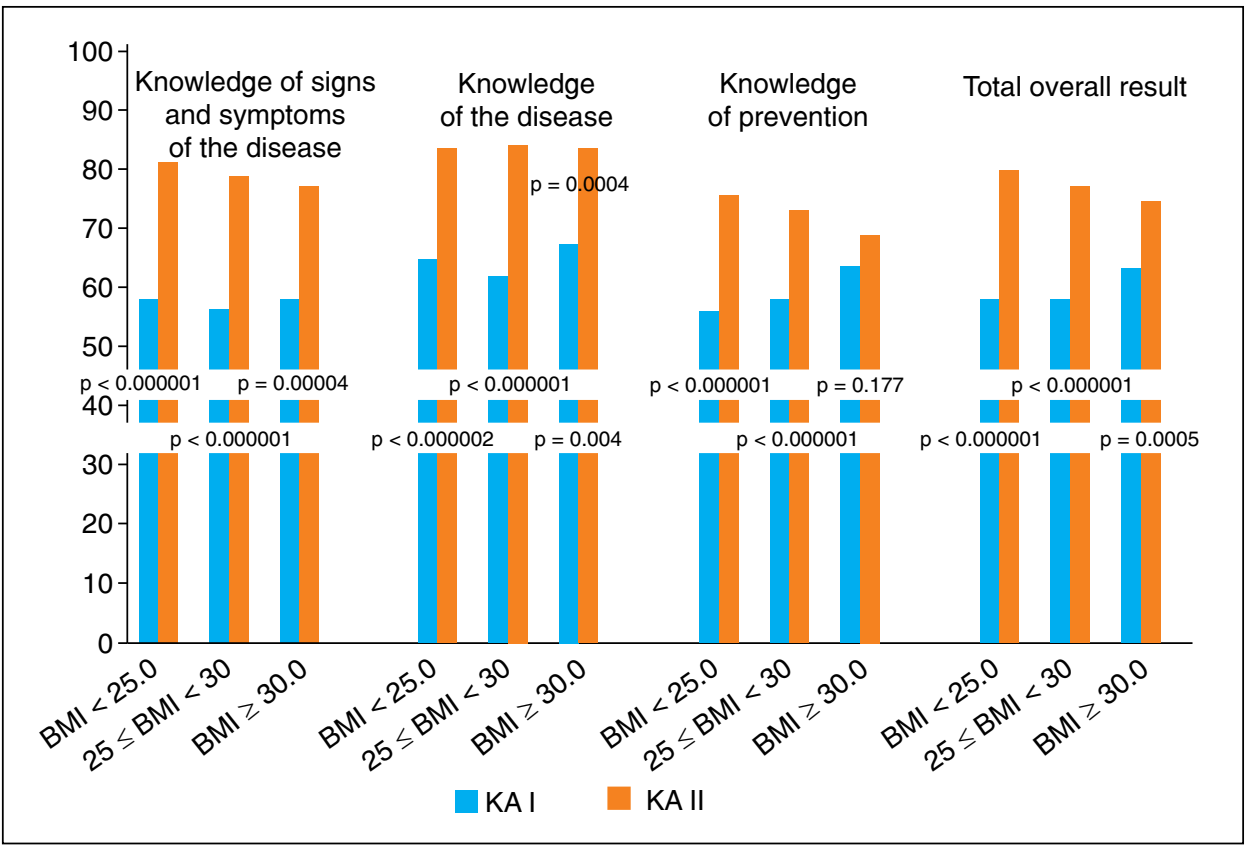

Figure 1. Comparison of the knowledge level at baseline (KA I) and at discharge (KA II) with regard to BMI.

Table 2. The comparison of the knowledge level (\% of correct answers) in patients before education (KA I) and after education (KA II) and the effectiveness of educational intervention ( $\triangle K A=K A I I-K A I)$ with regard to $B M I$.

\begin{tabular}{|c|c|c|c|c|c|c|c|}
\hline \multicolumn{2}{|c|}{ Knowledge assessment } & \multirow{3}{*}{$\begin{array}{l}\text { Total result } \\
\qquad \mathbf{n}=\mathbf{2 2 8}\end{array}$} & \multicolumn{5}{|c|}{ Body Mass Index (BMI) } \\
\hline \multirow{2}{*}{\multicolumn{2}{|c|}{$\begin{array}{l}\text { Range of } \\
\text { patients' } \\
\text { knowledge }\end{array}$}} & & $\mathrm{BMI}<25.0$ & $25 \leq \mathrm{BMI}<30$ & $\mathrm{BMI} \geq \mathbf{3 0 . 0}$ & $\mathbf{p}$ & $p$ for \\
\hline & & & $n=76$ & $n=104$ & $n=48$ & & \\
\hline \multirow{3}{*}{$\begin{array}{l}\text { Knowledge } \\
\text { of signs and } \\
\text { symptoms } \\
\text { of the disease }\end{array}$} & KA I & $57.54 \pm 22.96$ & $58.42 \pm 25.25$ & $56.73 \pm 6.46$ & $57.92 \pm 26.49$ & 0.95 & - \\
\hline & $\mathrm{KA} \|$ & $79.74 \pm 20.26$ & $81.8 \pm 418.81$ & $79.23 \pm 20.84$ & $77.50 \pm 21.29$ & 0.52 & - \\
\hline & $\triangle K A \|$ KA I & $22.19 \pm 28.17$ & $23.42 \pm 24.09$ & $22.50 \pm 32.34$ & $19.58 \pm 24.58$ & 0.75 & \\
\hline \multirow{3}{*}{$\begin{array}{l}\text { Knowledge } \\
\text { of the disease }\end{array}$} & KA I & $64.47 \pm 31.23$ & $65.26 \pm 32.56$ & $62.31 \pm 29.93$ & $67.92 \pm 32.15$ & 0.49 & - \\
\hline & KA II & $85.7 \pm 024.71$ & $88.16 \pm 25.34$ & $84.62 \pm 24.65$ & $84.17 \pm 24.04$ & 0.26 & - \\
\hline & $\Delta \mathrm{KA} \| \mathrm{I}-\mathrm{KAI}$ & $21.23 \pm 33.51$ & $22.89 \pm 34.05$ & $22.31 \pm 32.54$ & $16.25 \pm 34.92$ & 0.45 & - \\
\hline \multirow{3}{*}{$\begin{array}{l}\text { Knowledge } \\
\text { of prevention }\end{array}$} & KA I & $58.64 \pm 22.59$ & $56.32 \pm 21.22$ & $57.79 \pm 23.32$ & $64.17 \pm 22.68$ & 0.12 & - \\
\hline & KA II & $73.60 \pm 17.24$ & $76.18 \pm 16.41$ & $73.65 \pm 16.25$ & $69.38 \pm 19.94$ & 0.12 & - \\
\hline & $\Delta \mathrm{KA} I \mathrm{I}-\mathrm{KAI}$ & $14.96 \pm 25.09$ & $19.87 \pm 22.24$ & $15.87 \pm 25.60$ & $5.21 \pm 26.01$ & 0.012 & 0.005 \\
\hline \multirow{3}{*}{$\begin{array}{l}\text { Total overall } \\
\text { result }\end{array}$} & KA I & $59.82 \pm 19.36$ & $59.08 \pm 18.45$ & $58.65 \pm 19.30$ & $63.54 \pm 20.81$ & 0.24 & - \\
\hline & KA II & $78.16 \pm 15.07$ & $80.59 \pm 14.88$ & $77.79 \pm 14.16$ & $75.10 \pm 16.90$ & 0.08 & 0.022 \\
\hline & $\Delta \mathrm{KA} \| \mathrm{K}$ KAI & $18.33 \pm 19.86$ & $21.51 \pm 18.46$ & $19.13 \pm 20.10$ & $11.56 \pm 20.29$ & 0.027 & 0.010 \\
\hline
\end{tabular}

bolic syndrome, and microalbuminuria in patients with a lower level of education. On the other hand, Gardina et al. [21] indicated ethnic origin and education level as factors conditioning knowledge about symptoms of myocardial infarction. The authors did not confirm the impact of BMI on their knowledge.
Examination of patients' knowledge and the effectiveness of brochure-based educational intervention showed that obese patients acquired a significantly lower amount of knowledge, in particular, knowledge regarding prevention, as compared to patients with normal body mass. 
Cournot et al. [22] showed a negative correlation between $\mathrm{BMI}$ and results of cognitive functioning tests assessing attention, verbal memory, and fresh memory in middle-aged patients.

Jaracz et al. [23] also noted worse mental functioning in terms of thinking stiffness and reaction in obese people. Furthermore, the authors indicated worse results in the parameters assessing the effectiveness of thinking and the ability to maintain in memory and respond in accordance with the accepted logic concept [23].

Other researchers show poorer functioning of obese people in terms of concentration, endurance, and resistance to distractors [24].

It has been proven that excessive nutrition affects mental processes and behaviour [25]. Gomez-Pinilla et al. [26] confirmed that high-calorie foods, mainly those rich in saturated fatty acids and simple sugars, induce oxidative stress and reduce synaptic plasticity in the nervous system [26]. Alosco et al. [27] revealed a strong correlation between cognitive impairment and deposition of adipose tissue, especially abdominal fat. The authors prove that obesity through metabolic changes leads to changes in brain plasticity [27].

Taking into account the above-mentioned reports, the overweight and obese patients should not only be recognised as a high-risk group for cardiovascular diseases, but also as people who require intensified educational activities due to the worse cognitive functioning [28]. Perhaps combining different educational methods, increasing the frequency of educational meetings, and motivating to increase knowledge resources can lead to beneficial effects in the acquisition of knowledge about health and disease [29-32].

\section{Conclusions}

1. The brochure has proven to be an effective educational tool.

2. Educational interventions in overweight and obese patients should be intensified.

\section{References}

1. World Health Organization The challenge of obesity in the WHO European Region. Fact sheet EURO 2005;13:1-4. http://www.euro.who. int/_data/assets/pdf_file/0018/102384/fs1305e.pdf (2005).

2. Finucane MM, Stevens GA, Cowan MJ, et al. Global Burden of Metabolic Risk Factors of Chronic Diseases Collaborating Group (Body Mass Index). National, regional, and global trends in body-mass index since 1980: systematic analysis of health examination surveys and epidemiological studies with 960 country-years and $9 \cdot 1$ million participants. Lancet. 2011; 377(9765): 557-567, doi: 10.1016/S01406736(10)62037-5, indexed in Pubmed: 21295846.

3. Ng M, Fleming T, Robinson M, et al. Global, regional, and national prevalence of overweight and obesity in children and adults during 1980-2013: a systematic analysis for the Global Burden of Disease Study 2013. Lancet. 2014; 384(9945): 766-781, doi: 10.1016/S01406736(14)60460-8, indexed in Pubmed: 24880830.
4. Kasprzak M, Molska M, Obońska K, et al. Variability of prasugrel antiplatelet effect in patients with acute coronary syndrome. Medical Research Journal. 2015; 3(3): 117-124, doi: 10.5603/fmc.2015.0006.

5. Body-mass index and cause-specific mortality in 900000 adults: collaborative analyses of 57 prospective studies. The Lancet. 2009; 373(9669): 1083-1096, doi: 10.1016/s0140-6736(09)60318-4.

6. Räikkönen K, Matthews KA, Kuller LH. The relationship between psychological risk attributes and the metabolic syndrome in healthy women: antecedent or consequence? Metabolism. 2002; 51(12): 1573-1577, doi: 10.1053/meta.2002.36301, indexed in Pubmed: 12489070.

7. Benito-León J, Mitchell AJ, Hernández-Gallego J, et al. Obesity and impaired cognitive functioning in the elderly: a population-based cross-sectional study (NEDICES). Eur J Neurol. 2013; 20(6): 899-906, e76-7, doi: 10.1111/ene.12083, indexed in Pubmed: 23323838.

8. Piepoli MF Hoes AW Agewall S, et al. ESC Scientific Document Group. 2016 European Guidelines on cardiovascular disease prevention in clinical practice: The Sixth Joint Task Force of the European Society of Cardiology and Other Societies on Cardiovascular Disease Prevention in Clinical Practice (constituted by representatives of 10 societies and by invited experts)Developed with the special contribution of the European Association for Cardiovascular Prevention \& Rehabilitation (EACPR). Eur Heart J. 2016; 37(29): 2315-2381, doi: 10.1093/eurheartj/ehw106, indexed in Pubmed: 27222591.

9. Kubica A. Broszura - narzędzie edukacji zdrowotnej w kardiologii. Przyczynek do dyskusji o skuteczności profilaktyki wtórnej. Folia Cardiologica Excerpta. 2008; 3: 441.

10. Kubica A, Grześk G, Sinkiewicz W, et al. Compliance, concordance, adherence in chronic therapy. Folia Cardiol Excerpta. 2010; 5: 54-57.

11. Kubica A. Współpraca z pacjentem - podstawowy warunek skuteczności terapii w chorobie wieńcowej. Choroby Serca i Naczyń. 2009; 6: 131.

12. Kubica A. Psychologiczny aspekt zawału serca - niedoceniana zmienna w procesie terapii i rehabilitacji. Folia Cardiologica Excerpta. 2009; 4: 197

13. Smuclovisky C. Coronary Artery Disease. Coronary Artery CTA. 2009: 33-67, doi: 10.1007/978-1-4419-0431-7 3

14. Nutbeam D. Health literacy as a public health goal: a challenge for contemporary health education and communication strategies into the 21st century. Health Promotion International. 2000; 15(3): 259-267, doi: 10.1093/heapro/15.3.259.

15. Kubica A, Magielski P, OlejarczykE, et al. Źródła wiedzy a skuteczność edukacji u osób z ostrym zawałem serca. Folia Cardiologica. 2009; 4(5): 285-290

16. Michalski P, Kosobucka A, Pietrzykowski Ł, et al. Knowledge and learning preferences of patients with myocardial infarction. Med Res J. 2016; 1(4): 120-124, doi: 10.5603/mri.2016.0022.

17. Kubica A, Pufal J, Moczulska B, et al. Ocena wiedzy dotyczącej profilaktyki i objawów choroby niedokrwiennej serca u osób hospitalizowanych w klinice kardiologii. Psychiatr w Prakt Ogólnolek. 2004; 4: 135

18. Kubica A, Pufal J, Moczulska B, et al. Skuteczność edukacji zdrowotnej u osób hospitalizowanych w klinice kardiologii. Psychiat w Prakt Ogólnolek. 2005; 5: 61

19. Kubica A, Obońska K, Fabiszak T, et al. Adherence to antiplatelet treatment with P2Y12 receptor inhibitors. Is there anything we can do to improve it? A systematic review of randomized trials. Curr Med Res Opin. 2016; 32(8): 1441-1451, doi: 10.1080/03007995.2016.1182901, indexed in Pubmed: 27112628.

20. Di Chiara T, Scaglione A, Corrao S, et al. Association between low education and higher global cardiovascular risk. J Clin Hypertens (Greenwich). 2015; 17(5): 332-337, doi: 10.1111/jch.12506, indexed in Pubmed: 25703272

21. Giardina EGV, Mull L, Sciacca RR, et al. Relationship between cardiovascular disease knowledge and race/ethnicity, education, and weight status. Clin Cardiol. 2012; 35(1): 43-48, doi: 10.1002/clc.20992, indexed in Pubmed: 22083540.

22. Cournot M, Marquié JC, Ansiau D, et al. Relation between body mass index and cognitive function in healthy middle-aged men and women. Neurology. 2006; 67(7): 1208-1214, doi: 10.1212/01. wnl.0000238082.13860.50, indexed in Pubmed: 17030754.

23. Jaracz M, Bieliński M, Junik R, et al. Zaburzenia pamięci operacyjnej, funkcji wykonawczych i objawy depresji u osób z patologiczną otyłością. Psychiatria. 2009; 6(1): 9-14.

24. Cserjési R, Luminet $O$, Poncelet AS, et al. Altered executive function in obesity. Exploration of the role of affective states on cognitive abilities. Appetite. 2009; 52(2): 535-539, indexed in Pubmed: 19260167.

25. Koszowska A, Dittfeld A, Zubelewicz-Szkodzińska B. Psychologiczny aspekt odżywiania oraz wpływ wybranych substancji na zachowania i procesy myślowe. Hygeia Public Health. 2013; 48(3): 279-284.

26. Gomez-Pinilla F. The combined effects of exercise and foods in preventing neurological and cognitive disorders. Prev Med. 2011; 
52 Suppl 1: S75-S80, doi: 10.1016/j.ypmed.2011.01.023, indexed in Pubmed: 21281667

27. Alosco ML, Spitznagel MB, Gunstad J. Obesity as a risk factor for poor neurocognitive outcomes in older adults with heart failure. Heart Fail Rev. 2014; 19(3): 403-411, doi: 10.1007/s10741-013-9399-2, indexed in Pubmed: 23743688

28. Kubica A, Kasprzak M, Obońska K, et al. Impact of health education on adherence to clopidogrel and clinical effectiveness of antiplatelet treatment in patients after myocardial infarction. Med Res J. 2016 3(4): 154-159, doi: 10.5603/fmc.2015.0010.

29. Kubica J, Adamski P, Buszko K, et al. Rationale and Design of the Effectiveness of LowEr maintenanCe dose of TicagRelor early After my- cardial infarction (ELECTRA) pilot study. Eur Heart J Cardiovasc Pharmacother. 2017 [Epub ahead of print], doi: 10.1093/ehjcvp/pvx032, indexed in Pubmed: 29040445

30. Kubica A Sinkiewicz W Szymański $P$ et al. Edukacja zdrowotna w chorobach układu krążenia - możliwości i zagrożenia. Folia Cardiol Excerp. 2007; 2: 177.

31. Kubica A. Wybrane problemy prewencji wtórnej u chorych po incydentach wieńcowych. Folia Cardiol Excerp. 2008; 3: 366.

32. Kubica A, Kasprzak M, Obońska K, et al. Discrepancies in assessment of adherence to antiplatelet treatment after myocardial infarction. Pharmacology. 2015; 95(1-2): 50-58, doi: 10.1159/000371392, indexed in Pubmed: 25592409. 